\title{
Optic atrophy, cataracts, lipodystrophy/lipoatrophy, and peripheral neuropathy caused by a de novo OPA3 mutation
}

\begin{abstract}
Stephanie C. Bourne, ${ }^{1}$ Katelin N. Townsend, ${ }^{2,3}$ Casper Shyr, ${ }^{2,3}$ Allison Matthews, ${ }^{2,3}$ Scott A. Lear, ${ }^{4}$ Raj Attariwala, ${ }^{5}$ Anna Lehman, ${ }^{2}$ Wyeth W. Wasserman, ${ }^{2,3}$ Clara van Karnebeek, ${ }^{2,3}$ Graham Sinclair, ${ }^{6}$ Hilary Vallance, ${ }^{6}$ and William T. Gibson ${ }^{2,3}$

${ }^{1}$ Department of Microbiology and Immunology, Dalhousie University, Halifax, Nova Scotia B3H 4R2, Canada; ${ }^{2}$ Department of Medical Genetics, University of British Columbia, Vancouver, British Columbia V6T 1Z4, Canada; ${ }^{3}$ Child and Family Research Institute, British Columbia Children's Hospital, Vancouver, British Columbia V5Z 4H4, Canada; ${ }^{4}$ Faculty of Health Sciences, Simon Fraser University, Vancouver, British Columbia V5A 1S6, Canada; ${ }^{5}$ AIM Medical Imaging, Vancouver, British Columbia V6H 1C9, Canada; ${ }^{\circ}$ Department of Pathology, British Columbia Children's Hospital, Vancouver, British Columbia V6H 3N1, Canada
\end{abstract}

Abstract We describe a woman who presented with cataracts, optic atrophy, lipodystrophy/ lipoatrophy, and peripheral neuropathy. Exome sequencing identified a c.235C > G p.(Leu79Val) variant in the optic atrophy 3 (OPA3) gene that was confirmed to be de novo. This report expands the severity of the phenotypic spectrum of autosomal dominant OPA3 mutations.

[Supplemental material is available for this article.]

Corresponding author: wtgibson@cfri.ubc.ca

(c) 2017 Bourne et al. This article is distributed under the terms of the Creative Commons Attribution License, which permits unrestricted reuse and redistribution provided that the original author and source are credited.

Ontology terms: ataxia; congenital nuclear cataract; progressive peripheral neuropathy

Published by Cold Spring Harbor Laboratory Press

doi: $10.1101 / \mathrm{mcs} . a 001156$

\section{INTRODUCTION}

Pathogenic rare variants in OPA3 have previously been shown to cause optic atrophy, with either autosomal dominant or autosomal recessive inheritance (Sergouniotis et al. 2015). The OPA3 protein primarily localizes at the inner mitochondrial membrane and possibly the outer mitochondrial membrane (Grau et al. 2013). Although the exact function of OPA3 is unknown, previous studies have suggested OPA3 involvement in regulating mitochondrial morphology (Ryu et al. 2010; Grau et al. 2013).

Costeff syndrome, also known as type III 3-methylglutaconic aciduria, is caused by autosomal recessive OPA3 mutations and, to date, has been reported almost exclusively among patients of Iraqi-Jewish descent (Yahalom et al. 2014). Patients with Costeff syndrome usually present with early-onset bilateral optic atrophy, later-onset spasticity, extrapyramidal dysfunction, cerebellar ataxia, and mild cognitive defect (Anikster et al. 2001; Sofer et al. 2015). A significantly increased level of 3 -methylglutaconic acid $(>40 \mu \mathrm{mol} / \mathrm{mmol} \mathrm{Cr})$ in the urine of an individual with optic atrophy confirms a diagnosis of Costeff syndrome (Reynier et al. 2004; Pei et al. 2010; Wortmann et al. 2013).

Autosomal dominant OPA3 mutations causing optic atrophy appear to be less common than the recessive form, and the phenotypes, attributable to these rare variants, are more variable (Sergouniotis et al. 2015). Autosomal dominant optic atrophy (ADOA) caused by 
an OPA3 mutation usually presents with optic atrophy and cataracts, although some patients have been seen with isolated optic atrophy (Sergouniotis et al. 2015). Hearing loss, nystagmus, and glaucoma have also been observed in patients with ADOA caused by OPA3 mutations (Sergouniotis et al. 2015). Peripheral neuropathy and ataxia in these cases were first described in 1961 by Garcin and coworkers among a French family that manifested autosomal dominant inheritance of optic atrophy and cataract. Follow-up studies by Reynier et al. (2004) attributed this family's disorder to a c.277G > A, p.(Gly93Ser) mutation transition in exon 2 of OPA3, which cosegregated with the phenotype.

Here we describe a patient with optic atrophy, cataracts, ataxia, and peripheral and autonomic neuropathy associated with an autosomal dominant c. $235 \mathrm{C}>\mathrm{G}$ p.(Leu79Val) mutation in exon 2 of the OPA3 gene (National Center for Biotechnology Information [NCBI] reference sequence NM_025136.3).

\section{RESULTS}

\section{Clinical Presentation and Family History}

The female Caucasian proband presented with nystagmus at birth and bilateral cataracts that were first detected at 3 mo of age. Her lenses were removed during her first year, but there was no apparent improvement in her best-corrected visual acuity. At age $6 \mathrm{yr}$, she was found to have optic nerve atrophy after a visual evoked potentials (VEP) test. The VEP test concluded that the patient had highly abnormal visual evoked potentials in both eyes. She was otherwise healthy until $12 \mathrm{yr}$ of age when she started experiencing ataxia, which caused her to stumble. The ataxia initially manifested only in her lower limbs, and then her upper limbs began to show signs of ataxia at $\sim 15 \mathrm{yr}$ of age. She started experiencing falls at age 17 and was formally diagnosed with peripheral neuropathy after nerve conduction studies were performed at age 21. The nerve conduction studies showed a complete absence of all sensory responses in the upper and lower extremities. Motor nerve conduction studies in the upper limbs were normal, and there were no findings that suggested demyelination.

The patient recalled a relatively rapid progression of her neuropathy between 17 and 27 yr of age, though the progression has slowed for the last few years. Her visual acuity has worsened since birth, decreasing from $20 / 200$ as a young child to $20 / 450$ currently. She also has symptoms of palinopsia with smearing effect, double vision, and visual snow. By age $23 \mathrm{yr}$, she had cutis marmorata in her extremities, a novel phenotype for OPA3 mutations, suggesting some degree of vasomotor instability. She also has cerebellar findings including a marked intention tremor, dysdiadochokinesia, and mild dysarthria, suggesting there is a cerebellar component to her ataxia. She has an extrapyramidal component with some chorea, postural tremor, and vocal tremor. She has normal facial features with the exception of upslanting palpebral fissures and is of normal intelligence. The possibility of a secondary lipodystrophy was considered because she also has generalized wasting of muscle and subcutaneous fat, especially in the hands and forearms. She has diminished light touch sensation from knees distally and distal to the metacarpophalangeal joints of the hands. Blood biomarkers have been unremarkable over the last $10 \mathrm{yr}$, except for occasional mild neutropenia and mild elevations of creatine kinase and total cholesterol (Table 1). Urinalysis has shown moderate ketones and a slightly elevated vitamin $E$, though urine organic acids found no evidence of 3-methylglutaconic aciduria as her 3-methylglutaconic acid level was $9 \mathrm{mmol} / \mathrm{mol}$ of creatinine (reference range $<20 \mathrm{mmol} / \mathrm{mol} \mathrm{Cr}$ ). Her electromyography (EMG) showed chronic neurogenic changes, and brain magnetic resonance imagings (MRIs) performed at ages 20 and $23 \mathrm{yr}$ were normal with the exceptions of signs of bilateral optic nerve and chiasmal atrophy. There is no apparent cardiac involvement as demonstrated by a normal electrocardiogram and echocardiogram. 


\begin{tabular}{|c|c|c|}
\hline Biomarker & Patient serum concentration & Reference range \\
\hline Alanine aminotransferase & $22 \mathrm{U} / \mathrm{I}$ & $<36 \mathrm{U} / \mathrm{l}$ \\
\hline Albumin & $46 \mathrm{~g} / \mathrm{l}$ & $35-50 \mathrm{~g} / \mathrm{l}$ \\
\hline Alkaline phosphatase & $55 \mathrm{U} / \mathrm{l}$ & $<125 \mathrm{U} / \mathrm{I}$ \\
\hline Aspartate aminotransferase & $29 \mathrm{U} / \mathrm{I}$ & $<36 \mathrm{U} / \mathrm{l}$ \\
\hline Bilirubin & $14 \mu \mathrm{mol} / \mathrm{l}$ & $3-17 \mu \mathrm{mol} / \mathrm{l}$ \\
\hline Ceruloplasmin & $235 \mathrm{mg} / \mathrm{l}$ & 220-455 mg/l \\
\hline Cholesterol & $5.0 \mathrm{mmol} / \mathrm{l}$ & $2.0-4.6 \mathrm{mmol} / \mathrm{l}$ \\
\hline HDL cholesterol & $1.6 \mathrm{mmol} / \mathrm{l}$ & $>1.1 \mathrm{mmol} / \mathrm{l}$ \\
\hline LDL cholesterol & $3.1 \mathrm{mmol} / \mathrm{l}$ & $1.5-3.0 \mathrm{mmol} / \mathrm{l}$ \\
\hline Cholesterol-to-HDL ratio & 3.1 & $>4.4$ \\
\hline Copper & $13.1 \mu \mathrm{mol} / \mathrm{l}$ & $11.3-25.2 \mu \mathrm{mol} / \mathrm{l}$ \\
\hline Creatine kinase & $169 \mathrm{U} / \mathrm{l}$ & $<140 \mathrm{U} / \mathrm{I}$ \\
\hline Ferritin & $15 \mu \mathrm{g} / \mathrm{l}$ & $15-200 \mu \mathrm{g} / \mathrm{l}$ \\
\hline Folate & $755 \mathrm{nmol} / \mathrm{l}$ & $>12 \mathrm{nmol} / \mathrm{l}$ \\
\hline$\gamma$-Glutamyl transferase & $14 \mathrm{U} / \mathrm{l}$ & $<31 \mathrm{U} / \mathrm{l}$ \\
\hline Glucose (fasting) & $4.7 \mathrm{mmol} / \mathrm{l}$ & $3.6-6.0 \mathrm{mmol} / \mathrm{l}$ \\
\hline Homocysteine & $7.0 \mathrm{mmol} / \mathrm{l}$ & $<7.8 \mathrm{mmol} / \mathrm{l}$ \\
\hline Lactic acid & $0.7 \mathrm{mmol} / \mathrm{l}$ & $0.5-2.2 \mathrm{mmol} / \mathrm{l}$ \\
\hline Triglyceride & $0.6 \mathrm{mmol} / \mathrm{l}$ & $<2.3 \mathrm{mmol} / \mathrm{l}$ \\
\hline Urea & $7 \mathrm{mmol} / \mathrm{l}$ & 2-9 $\mathrm{mmol} / \mathrm{l}$ \\
\hline
\end{tabular}

$H D L$, high-density lipoprotein; LDL, low-density lipoprotein.

She experiences constant paresthesia and numbness in her extremities. Diminished light touch sensation in her hands and feet make it difficult for her to distinguish textures. She also experiences proximal muscle weakness. She has lost position sense in her distal interphalangeal joints in both her hands and feet. Deep tendon reflexes are absent in her ankles, knees, and wrists. She has hyperesthesia of her lower legs, particularly of the soles of her feet. She also has atrophy of the fat pads of her face and has experienced neuropathic pain in her hands and feet. She has an ataxic gait and has reduced hearing in her left ear $(512 \mathrm{mHz})$. Her parents and two siblings showed no signs of sharing her phenotype.

\section{Genomic Analysis}

At age 20, medical genetics first assessed her to search for a potential diagnosis. She had normal chromosomes and a normal test for Friedreich's ataxia. Genes associated with Charcot-Marie-Tooth disease (MPZ, MFN2, and GJB1) were sequenced also, as CharcotMarie-Tooth disease presents with progressive atrophy and muscle weakness secondary to neuropathy (Roa et al. 1996; Züchner et al. 2004; Rouzier et al. 2012). The common duplication of PMP22 was ruled out by clinical-grade testing, and genes known to cause lipodystrophy (LMNA, PPARG, EMD, AGPAT2, BSCL2) were also sequenced. No pathogenic variants were found in any of these genes. Testing of OPA3 as a candidate gene by an external laboratory on a research basis did not identify any rare variants, so trio-based exome sequencing was performed on blood-derived DNA from the patient and her parents. The sequencing results identified a de novo missense variant (c.235C > G p.[Leu79Val]) in the patient's OPA3 gene (NCBI reference sequence NM_025136.3), a gene known to cause optic atrophy and cataracts (Reynier et al. 2004; Ayrignac et al. 2012). Sanger confirmation of 


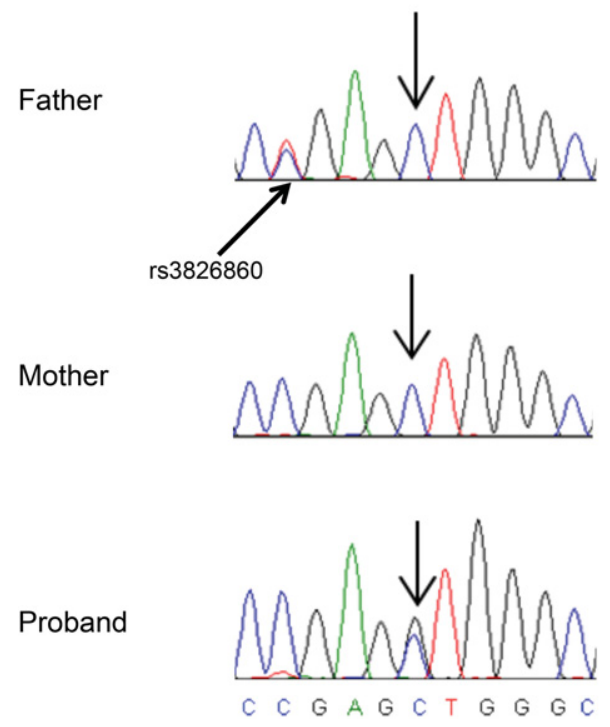

Figure 1. Sanger sequencing traces with arrows indicating the mutation and a nearby single-nucleotide polymorphism (SNP). Traces show that the OPA3 variant (Chr19:46,057,077C > G p.(L79V) annotated per hg19) is de novo in the proband. The father is heterozygous for rs3826860, a synonymous variant that is annotated in the Database for Short Genetic Variations (dbSNP) at a nearby nucleotide (g.46,057,081A > G; c.231T > C; p. $($ Ala77=)); the proband and her mother are homozygous for the SNP, whereas only the proband is heterozygous for the mutation.

the variant of interest was carried out using standard polymerase chain reaction (PCR) in the proband and in parental DNA. Sanger sequencing confirmed that the proband was heterozygous for the variant and that the variant was absent from both parents (Fig. 1). The variant is absent from the Database for Short Genetic Variations (dbSNP) build 146, National Heart, Lung, and Blood Institute (NHLBI) Exome Variant Server, and Exome Aggregation Consortium (ExAC) (Table 2). The genomic position is highly conserved in vertebrates and is predicted to be damaging by Combined Annotation-Dependent Depletion (CADD) (CADD version 1.3 score was 19.02), MutationTaster (probability 0.999311228255692), and Protein Variation Effect Analyzer (PROVEAN) software (PROVEAN score was -3.00, with anything less than -2.5 considered to be deleterious; Choi 2012; Choi et al. 2012). OPA3 has a residual variation intolerance score (RVIS) of 20.96, which suggests it is not a gene that is frequently seen to harbor rare benign mutations, thereby further supporting the pathogenicity of our de novo variant. Parental relatedness to the proband was confirmed. There were no other variants detected in any genes that are known to cause Charcot-MarieTooth disease or other diseases with a similar phenotype (average read coverage, $37.5 \times$ ).

Table 2. OPA3 variant summary

\begin{tabular}{ccccccc}
\hline Gene & $\begin{array}{c}\text { Chr. } \\
\text { (hg19) }\end{array}$ & Position & Mutation & $\begin{array}{c}\text { Amino acid } \\
\text { change }\end{array}$ & Inheritance & $\begin{array}{c}\text { Public database } \\
\text { reference }{ }^{a}\end{array}$ \\
\hline OPA3 & 19 & g.46,057,077G $>$ C & NM_025136.3 & p.Leu79Val & De novo & Not described
\end{tabular}

aPublic databases checked include Database for Short Genetic Variations (dbSNP) build 146, National Heart, Lung, and Blood Institute (NHLBI) Exome Variant Server, and Exome Aggregation Consortium (ExAC). 


\section{DISCUSSION}

The patient presented with an unusually severe phenotype for autosomal dominant optic atrophy caused by an OPA3 mutation. Certain aspects of her phenotype have been observed in others with heterozygous mutations in this gene, though rarely to this degree. In addition to the known features of optic atrophy and cataracts, she has peripheral motor and sensory neuropathy as well as evidence of autonomic neuropathy. Although neurological symptoms, such as extrapyramidal signs and ataxia, have been associated with autosomal dominant OPA3 mutations, this is the first documented case of severe neuropathy (Garcin et al. 1961; Reynier et al. 2004). She also has occasional difficulties swallowing and frequent episodes of abdominal pain with alternating constipation and diarrhea. Gastrointestinal symptoms were also reported in a French family with a heterozygous c.313C > G, p.(Gln105Glu) OPA3 mutation (Ayrignac et al. 2012).

The patient also has periodic lightheadedness, urinary symptoms, and a variable body temperature further suggesting autonomic nervous system involvement. Her urine organic acid profile (run twice on two different occasions) was normal with the exception of moderate ketone levels and the presence of myoglobin. Normal organic acid profiles are not uncommon in individuals with autosomal dominant OPA3 mutations (Reynier et al. 2004). She has pain in her extremities, reduced hearing in her left ear, and gait abnormalities, which are all previously associated with mutations in OPA3 (Ayrignac et al. 2012; Sergouniotis et al. 2015). She has also experienced rapid weight loss since age 20 and is now in the $<5$ th percentile of weight for her height. Metabolic testing was performed and the results showed that her resting energy expenditure was $\sim 84 \%$ of that predicted for her age, but an adjusted resting energy expenditure was calculated and was relatively high compared to controls similar to her size (Supplemental Tables S1-S4). Whether she has true lipodystrophy (abnormal growth and/or loss of adipose tissue due to a primary, intrinsic defect of the tissue) as opposed to lipoatrophy (loss of adipose tissue secondary to hypermetabolism) could not be established with certainty, though her relatively high metabolic rate suggests the possibility of the former. Mouse models with a homozygous mutation in Opa3 showed a 60\% reduction in body weight and profound intra-abdominal leanness, suggesting that the patient's loss of adipose tissue may be caused by her OPA3 mutation (Davies et al. 2008; Wells et al. 2012; Navein et al. 2016). The atypical set of phenotypes observed in this case expands the phenotypic spectrum of autosomal dominant mutations in OPA3 and identifies a de novo mutation, which we believe to be pathogenic for these phenotypes. However, additional functional studies or cases with a similar phenotype will be necessary to confirm the pathogenicity of autosomal dominant variants in OPA3.

\section{METHODS}

\section{Exome Sequencing}

Genomic DNA was extracted from whole blood collected from the affected patient and her parents and trio-based exome sequencing was performed at PerkinElmer corporation using Agilent V4 $51 \mathrm{Mb}$ capture with sequencing of 100-bp paired-end reads on an Illumina HiSeq 2000 at average $30 \times$ coverage across the known exons (Table 3). Data analysis was carried out using an in-house bioinformatics pipeline to align the FASTO reads to the human genome reference version 19 (GRCh37.75) and to identify and assess the predicted effect of rare $(<3 \%$ allelic frequency from dbSNPv146) variants on protein function (Shyr et al. 2014). De novo dominant-, recessive-, and X-linked modes of inheritance were assessed through in-house scripts, and variants altering the protein code were selected (missense, 


\begin{tabular}{lccccc}
\hline Table 3. Sequence coverage & $\begin{array}{c}\text { Number of } \\
\text { starting paired- } \\
\text { end reads }\end{array}$ & $\begin{array}{c}\text { Percentage of } \\
\text { reads aligned }\end{array}$ & $\begin{array}{c}\text { Median } \\
\text { read } \\
\text { coverage }\end{array}$ & $\begin{array}{c}\text { Percentage of } \\
\text { coding sites with } \\
\text { >20-fold coverage }\end{array}$ & $\begin{array}{c}\text { Percentage of } \\
\text { OPA3 sites with } \\
\text { >10-fold coverage }\end{array}$ \\
\hline Sample & 82.1 & 37.5 & 93.5 & 100 \\
Mother & $67,382,674$ & 79.3 & 33.6 & 90.1 & 100 \\
Father & $59,968,033$ & 83.6 & 32.1 & 88.6 & 100 \\
\hline
\end{tabular}

nonsense, frameshift changes, in-frame deletions, and splice-site effects) (Table 4). Remaining variants were quality-screened manually using the Integrative Genomics Viewer (https://www.broadinstitute.org/igv/). The variants were narrowed down based on their clinical significance and similarity to the phenotype.

\section{Sanger Sequencing}

Sanger sequencing of the variant of interest within the OPA3 gene was carried out on DNA amplified by standard PCR. PCR reactions were prepared in a $20 \mu \mathrm{l}$ volume with $40 \mathrm{ng}$ genomic DNA, 1× GoTaq Green Mastermix (Promega), 5\% dimethyl sulfoxide (DMSO) (Sigma-Aldrich), and $0.25 \mu \mathrm{M}$ of the primer pair. Primers were designed by Life Technologies (OPA3, Hs00760967_CE; forward, 5'-GCCAGTACTCCAGCACTAGG-3', reverse, 5'-CTGCATTCCCTGGGTGAGAG-3'). The PCR began with a 2 -min cycle at $94^{\circ} \mathrm{C}$, followed by 35 cycles of $45 \mathrm{sec}$ at $94^{\circ} \mathrm{C}, 45 \mathrm{sec}$ at $63^{\circ} \mathrm{C}$, and $1 \mathrm{~min}$ at $72^{\circ} \mathrm{C}$, ending with extension for $10 \mathrm{~min}$ at $72^{\circ} \mathrm{C}$. Sanger sequencing was carried out on an $\mathrm{ABI} 3130 \mathrm{xl}$.

\section{Indirect Calorimetry}

The canopy (dilution) method was used to obtain indirect calorimetry information. Ambient and diluted fractions of $\mathrm{O}_{2}$ and $\mathrm{CO}_{2}$ were measured for a known ventilation rate. $\mathrm{O}_{2}$ consumption and $\mathrm{CO}_{2}$ production were determined and converted into resting energy expenditure. The abbreviated Weir equation (without urinary nitrogen) was used to convert gas exchange measures into resting energy expenditure.

\section{ADDITIONAL INFORMATION}

\section{Data Deposition and Access}

Exome sequencing data is not publicly available because patient consent could not be obtained. The variant found in the proband has been deposited into ClinVar (http://www.ncbi. nlm.nih.gov/clinvar/) under accession number SCV000266846.

\begin{tabular}{lccc}
\hline Table 4. Variants identified from exome sequencing & & \\
\hline & $\begin{array}{c}\text { Filtering } \\
\text { results }\end{array}$ & $\begin{array}{c}\text { Manual } \\
\text { review }\end{array}$ & $\begin{array}{c}\text { Resulting genes } \\
\text { of interest }\end{array}$ \\
\hline $\begin{array}{l}\text { Homozygous (\# seq. changes) } \\
\begin{array}{l}\text { Compound heterozygous (\# seq. } \\
\text { changes) }\end{array}\end{array}$ & $4(4)$ & $0(0)$ & $0(0)$ \\
$\begin{array}{l}\text { De novo genes (\# seq. changes) } \\
\text { X-linked genes (\# seq. changes) }\end{array}$ & $28(28)$ & $0(0)$ & $0(0)$ \\
Total genes (\# seq. changes) & $9(9)$ & $2(2)$ & $1(1)$ \\
\hline
\end{tabular}


Competing Interest Statement

The authors have declared no competing interest.

Received April 17, 2016 accepted in revised form October 20, 2016.
OPA3 mutation causing peripheral neuropathy

\section{Ethics Statement}

Written informed consent was obtained for collecting blood samples and sequencing from all study participants. The studies conducted here were approved by the Institutional Review Boards of Simon Fraser University and of UBC/Children's and Women's Health Centre of British Columbia.

\section{Acknowledgments}

We thank the patient and her family for their generous contribution. We also gratefully acknowledge Selina Gyawali (Simon Fraser University) and Wayne Picker (AIM Medical Imaging) for performing the imaging studies.

\section{Author Contributions}

S.C.B. analyzed the data, drafted, and critically reviewed the manuscript. K.N.T. analyzed the data and critically reviewed the manuscript. C.S., A.L., and A.M. provided and analyzed the exome data. R.A. and S.A.L. analyzed the imaging studies. W.W.W. and C.v.K. analyzed the data. G.S and H.V. analyzed the urine organic acids data. W.T.G. conceived of the study, performed multiple clinical assessments, analyzed the data, and drafted and critically reviewed the manuscript.

\section{Funding}

This work was supported by the Canadian Institutes of Health Research (CIHR; Operating Grants PCN102990, PCN110794, MOP119595) and by Clinician Scientist salary awards to W.T.G. (CIHR and Child and Family Research Institute).

\section{REFERENCES}

Anikster Y, Kleta R, Shaag A, Gahl WA, Elpeleg O. 2001. Type III 3-methylglutaconic aciduria (optic atrophy plus syndrome, or Costeff optic atrophy syndrome): identification of the OPA3 gene and its founder mutation in Iraqi Jews. Am J Hum Genet 69: 1218-1224.

Ayrignac X, Liauzun C, Lenaers G, Renard D, Amati-Bonneau P, de Sèze J, Dollfus H, Hamel C, Bonneau D, Labauge P. 2012. OPA3-related autosomal dominant optic atrophy and cataract with ataxia and areflexia. Eur Neurol 68: 108-110.

Choi Y. 2012. A fast computation of pairwise sequence alignment scores between a protein and a set of singlelocus variants of another protein. In Proceedings of the ACM Conference on Bioinformatics, Computational Biology and Biomedicine (BCB'12), pp. 414-417. ACM, New York.

Choi Y, Sims GE, Murphy S, Miller JR, Chan AP. 2012. Predicting the functional effect of amino acid substitutions and indels. PLoS One 7: e46688.

Davies VJ, Powell KA, White KE, Yip W, Hogan V, Hollins AJ, Davies JR, Piechota M, Brownstein DG, Moat SJ, et al. 2008. A missense mutation in the murine Opa3 gene models human Costeff syndrome. Brain 131: 360-380.

Garcin R, Raverdy P, Delthil S, Man HX, Chimenes H. 1961. [Sur une affection hérédo-familiale associant cataracte, atrophie optique, signes extra-pyramidaux et certains stigmates de la maladie de Friedreich. (Sa position nosologique par rapport au syndrome de Behr, au syndrome de Marinesco-Sjogren et à la maladie de Friedreich avec signes oculaires).] Rev Neurol 104: 373-379.

Grau T, Burbulla LF, Engl G, Delettre C, Delprat B, Oexle K, Leo-Kottler B, Roscioli T, Krüger R, Rapaport D, et al. 2013. A novel heterozygous OPA3 mutation located in the mitochondrial target sequence results in altered steady-state levels and fragmented mitochondrial network. J Med Genet 50: 848-858.

Navein AE, Cooke EJ, Davies JR, Smith TG, Wells LH, Ohazama A, Healy C, Sharpe PT, Evans SL, Evans BA, et al. 2016. Disrupted mitochondrial function in the Opa3L122P mouse model for Costeff Syndrome impairs skeletal integrity. Hum Mol Genet. doi: 10.1093/hmg/ddw107.

Pei W, Kratz LE, Bernardini I, Sood R, Yokogawa T, Dorward H, Ciccone C, Kelley Rl, Anikster Y, Burgess HA, et al. 2010. A model of Costeff syndrome reveals metabolic and protective functions of mitochondrial OPA3. Development 137: 2587-2596. 
Reynier P, Amati-Bonneau P, Verny C, Olichon A, Simard G, Guichet A, Bonnemains C, Malecaze F, Malinge MC, Pelletier JB, et al. 2004. OPA3 gene mutations responsible for autosomal dominant optic atrophy and cataract. $J$ Med Genet 41: e110.

Roa BB, Warner LE, Garcia CA, Russo D, Lovelace R, Chance PF, Lupski JR. 1996. Myelin protein zero (2Mpz) gene mutations in nonduplication type 1 Charcot-Marie-Tooth disease. Hum Mutat 7: 36-45.

Rouzier C, Bannwarth S, Chaussenot A, Chevrollier A, Verschueren A, Bonello-Palot N, Fragaki K, Cano A, Pouget J, Pellissier JF, et al. 2012. The MFN2 gene is responsible for mitochondrial DNA instability and optic atrophy 'plus' phenotype. Brain 135: 23-34.

Ryu SW, Jeong HJ, Choi M, Karbowski M, Choi C. 2010. Optic atrophy 3 as a protein of the mitochondrial outer membrane induces mitochondrial fragmentation. Cell Mol Life Sci 67: 2839-2850.

Sergouniotis PL, Perveen R, Thiselton DL, Giannopoulos K, Sarros M, Davies JR, Biswas S, Ansons AM, Ashworth JL, Lloyd C, et al. 2015. Clinical and molecular genetic findings in autosomal dominant OPA3related optic neuropathy. Neurogenetics 16: 66-75.

Shyr C, Tarailo-Graovac M, Gottlieb M, Lee J, van Karnebeek CDM, Wasserman WW. 2014. FLAGS, frequently mutated genes in public exomes. BMC Med Genomics 7: 64 .

Sofer S, Schweiger A, Blumkin L, Yahalom G, Anikster Y, Lev D, Ben-Zeev B, Lerman-Sagie T, Hassin-Baer S. 2015. The neuropsychological profile of patients with 3-methylglutaconic aciduria type III, Costeff syndrome. Am J Med Genet B Neuropsychiatr Genet 168B: 197-203.

Wells T, Davies JR, Guschina IA, Ball DJ, Davies JS, Davies VJ, Evans BA, Votruba M. 2012. Opa3, a novel regulator of mitochondrial function, controls thermogenesis and abdominal fat mass in a mouse model for Costeff syndrome. Hum Mol Genet 21: 4836-4844.

Wortmann SB, Duran M, Anikster Y, Barth PG, Sperl W, Zschocke J, Morava E, Wevers RA. 2013. Inborn errors of metabolism with 3-methylg lutaconic aciduria as discriminative feature: proper classification and nomenclature. J Inherit Metab Dis 36: 923-928.

Yahalom G, Anikster Y, Huna-Baron R, Hoffmann C, Blumkin L, Lev D, Tsabari R, Nitsan Z, Lerman SF, BenZeev B, et al. 2014. Costeff syndrome: clinical features and natural history. J Neurol 261: 2275-2282.

Züchner S, Mersiyanova IV, Muglia M, Bissar-Tadmouri N, Rochelle J, Dadali EL, Zappia M, Nelis E, Patitucci A, Senderek J, et al. 2004. Mutations in the mitochondrial GTPase mitofusin 2 cause Charcot-Marie-Tooth neuropathy type 2A. Nat Genet 36: 449-451. 


\section{COLD SPRING HARBOR Molecular Case Studies}

\section{Optic atrophy, cataracts, lipodystrophy/lipoatrophy, and peripheral neuropathy caused by a de novo OPA3 mutation}

Stephanie C. Bourne, Katelin N. Townsend, Casper Shyr, et al.

Cold Spring Harb Mol Case Stud 2017, 3: a001156 originally published online October 28, 2016 Access the most recent version at doi: $10.1101 /$ mcs.a001156
Supplementary http://molecularcasestudies.cshlp.org/content/suppl/2016/10/28/mcs.a001156.D Material C1
References This article cites 19 articles, 3 of which can be accessed free at: http://molecularcasestudies.cshlp.org/content/3/1/a001156.full.html\#ref-list-1
License This article is distributed under the terms of the Creative Commons Attribution License, which permits unrestricted reuse and redistribution provided that the original author and source are credited.
Email Alerting Receive free email alerts when new articles cite this article - sign up in the box at the Service top right corner of the article or click here.

